\title{
Peningkatan Keterampilan Proses Sains dan Pemahaman Konsep melalui Model Learning Cycle 5E Berbantuan Virtual Lab pada Materi Usaha dan Energi
}

\author{
Nora Ilfira Yulasti, Nyoman Rohadi, Desy Hanisa Putri \\ Program Studi S1 Pendidikan Fisika, Jurusan Pendidikan MIPA \\ Fakultas Keguruan dan Ilmu Pendidikan, Universitas Bengkulu \\ Jalan W.R Supratman, Kandang Limun, Bengkulu 38123 \\ E-mail : Ilfiranora@gmail.com
}

\begin{abstract}
ABSTRAK
Telah dilakukan penelitian yang bertujuan meningkatkan aktivitas, keterampilan proses sains dan pemahaman konsep siswa dengan penelitian tindakan kelas tiga siklus. Subjek penelitian yaitu siswa kelas X MIPA 2 Kota Bengkulu. instrumen yang digunakan dalam penelitian ini yaitu lembar observasi dan lembar tes siswa. Hasil analisis observasi aktivitas siswa siklus I rata-rata 25 (Baik), siklus II 27 (baik), siklus III 29 (Baik). KPS siklus I pada aspek mengamati rata-rata 81.6 (Terampil), siklus II 90.8 (Sangat Terampil), siklus III 95.4 (Sangat Terampil), mengajukan pertanyaan siklus I rata-rata 74.67 (Terampil), siklus II 86.2 (Sangat Terampil), siklus III 95.4 (Sangat Terampil), merumuskan hipotesis siklus I rata-rata 49.1 (Kurang Terampil), siklus II 64.65 (Cukup Terampil) dan siklus III 95.4 (Sangat Terampil), menerapkan konsep siklus I rata-rata 66.2 (Cukup Terampil), siklus II 96.52 (Sangat Terampil), siklus III 97.24 (Sangat Terampil) dan aspek mengkomunikasikan siklus I rata-rata 82.72 (Terampil), pada siklus II 96.52 (Sangat Terampil) dan siklus III 97.24 (Sangat Terampil). Pada pemahaman konsep pada siklus I rata-rata 70.17, Ds 70.17\%, dan Kb 55.17\%, pada siklus II rata-rata 77.72, Ds $77.72 \%$, dan $\mathrm{Kb} 89.19 \%$ dan siklus III rata-rata 89.19, Ds 89.19\%, dan Kb 86.20\%. Disimpulkan, pembelajaran dengan penerapan model Learning Cycle $5 E$ berbantuan virtual Lab. dapat meningkatkan KPS dan pemahaman konsep siswa.
\end{abstract}

Kata kunci : Aktivitas Siswa, Keterampilan Proses Sains, Pemahaman Konsep, Model Learning Cycle 5E, Virtual Lab.

\section{ABSTRACT}

Research has been carried out that aims to increase activity, science process skills and students' understanding of concepts with three-cycle classroom action research. research subjects were students of class X MIPA 2 Bengkulu City. The instruments used in this study are observation sheets and student test sheets. results of analysis of observations of student activities. The results of the observation analysis of student activity in the first cycle were 25 (Good), cycle II 27 (good), cycle III 29 (Good). Cycle I in the aspect of observing an average of 81.6 (Skilled), cycle II 90.8 (Very Skilled), cycle III 95.4 (Very Skilled), asking questions on cycle I on average 74.67 (Skilled), cycle II 86.2 (Very Skilled), cycle III 95.4 (Very Skillful), formulate the first cycle hypothesis 49.1 (Less Skillful), cycle II 64.65 (Skillful enough) and cycle III 95.4 (Very Skillful), applying the concept of the average cycle I 66.2 (Simply Skilled), cycle II 96.52 (Very Skillful), cycle III 97.24 (Very Skillful) and aspects of communicating cycle I on average 82.72 (Skilled), in cycle II 96.52 (Very Skilled) and cycle III 97.24 (Very Skilled). On the understanding of the concept in the first cycle on average 70.17, Ds $70.17 \%$, and $\mathrm{Kb} 55.17 \%$, in cycle II on average 77.72, Ds $77.72 \%$, and $\mathrm{Kb} 89.19 \%$ and cycle III on average 89.19 , Ds $89.19 \%$, and $\mathrm{Kb} 86.20 \%$. It was concluded, learning by applying the virtual assisted 5E Learning Cycle model Lab. can increase PPP and students' understanding of concepts.

Keywords: Student Activity, Science Process Skills, Concept Understanding, 5E Learning Cycle Model, Virtual Lab.

\section{PENDAHULUAN}

Guru dan peserta didik memiliki peran masing-masing saat Proses Belajar Mengajar (PBM) berlangsung. Pada kurikulum 2013 ini peserta didik dan guru dituntut untuk lebih aktif. Peserta didik dituntut 
untuk lebih aktif dalam Proses Belajar Mengajar (PBM), bisa mencari sumber ilmu lain selain dari guru, seperti mencari ilmu menggunakan internet atau sumber lainnya, karena pada Kurikulum 2013 guru bukanlah satu-satunya sumber ilmu bagi peserta didik. Guru merupakan salah satu faktor yang sangat penting dalam Proses Belajar Mengajar (PBM). Guru sebagai fasilitator dalam Proses Belajar Mengajar (PBM) diharapkan mampu menciptakan situasi yang kondusif atau dapat dikatakan situasi yang tenang sesuai dengan yang diharapkan untuk belajar, sehingga dapat meningkatkan potensi peserta didik, oleh karena itu guru dituntut membuat Rencana Pelaksanaan Pembelajaran (RPP) dan menerapkan model pembelajaran yang menarik untuk meningkatkan keterampilan proses sains dan pemahaman konsep peserta didik. Menurut penelitian yang dilakukan oleh Dina, Rosane \& Nyoman keberhasilan proses pembelajaran bukan hanya dilihat dari hasil belajar siswa tapi juga pada proses pembelajaran tersebut. Proses pembelajaran tidak terlepas dari aktivitas guru dan peserta didik [1].

Kenyataan di lapangan keterampilan proses sains dan pemahaman konsep peserta didik pada mata pelajaran fisika bisa dikatakan masih cukup rendah. Hal ini disebabkan kurangnya pemahaman siswa pada materi fisika dan banyak peserta didik yang menganggap bahwa pelajaran fisika itu sulit dan kurang menarik. Kurang menariknya pelajaran fisika dapat disebabkan karena berbagai faktor, salah satunya kurang tepatnya metode pembelajaran yang digunakan oleh guru pada Proses Belajar Mengajar (PBM). Pada pembelajaran fisika, guru pada umumnya masih banyak yang menggunakan metode ceramah dan model yang kurang bervariasi sehingga kurang memberikan kesempatan pada peserta didik untuk berpartisipasi dalam Proses Belajar Mengajar (PBM) dikarenakan peran guru lebih banyak sebagai sumber belajar yang menyebabkan peserta didik menjadi kurang aktif dalam Proses Belajar Mengajar (PBM). Kurangnya keterampilan proses sains dan pemahaman konsep dapat dilihat pada saat proses praktikum berlangsung dan dilakukan pada akhir pembelajaran, saat proses praktikum berlangsung banyak peserta didik yang kurang terampil dan kurang aktif sehingga saat dilakukan tes pada akhir pembelajaran hasil nilai yang didapatkan masih banyak yang di bawah kriteria ketuntasan minumum (KKM) yaitu 75, tes yang dilakukan pada akhir pembelajaran atau yang sering disebut dengan post test berguna untuk mengetahui sejauh mana keterampilan proses sains dan pemahaman konsep peserta didik tersebut, sehingga dapat dikatakan bahwa penguasaan materi dan keterampilan proses peserta didik masih kurang atau dikatakan belum mencukupi.

Salah satu model yang dapat digunakan untuk meningkatkan keterampilan proses sains serta kemampuan pemahaman konsep siswa adalah Model pembelajaran Learning Cycle $5 E$ yang merupakan model siklus belajar yang melibatkan siswa secara aktif melalui 5 fase dalam pembelajaran, kegiatan-kegiatan yang dilakukan dalam model pembelajaran Learning Cycle 5E sebagai berikut: a) tahap Engagement (terlibat), pada tahap ini peserta didik dilibatkan secara mental untuk terlibat dalam proses pembelajaran seperti mengajukan pertanyaan, mendefiniskan peristiwa/kasus yang menimbulkan pertanyaan serta dapat meningkatkan minat dan membantu dalam membuat hubungan antara apa yang ingin peserta didik ketahui dan apa yang peserta didik dapat lakukan; b) Tahap Exploration, pada tahap ini peserta didik melakukan eksplorasi yang dirancang khusus agar dapat memperoleh pengalaman nyata untuk mulai membangun konsep, dan pengalaman yang diberikan dapat digunakan untuk mengenalkan konsep, proses, atau keterampilan; c) Tahap Explanation, pada peserta didik diberikan waktu untuk menyampaikan penjelasannya, kemudian guru menjelaskan persamaan atau konsep berdasarkan penjelasan dari yang dipaparkan oleh peserta didik d) Tahap Elaboration, pada tahap ini peserta didik dilatih untuk mampu menerapkan apa yang telah dipelajarinya; e) Tahap Evaluation, pada tahap ini guru mengevaluasi pemahaman peserta didik menganai konsep dan penguasaan keterampilan bisa dilakukan dengan pemberian tes tertulis pada akhir pembelajaran dan dengan bantuan virtual lab. dengan manfaatnya yaitu ekonomis karena tidak membutuhkan alat-alat dan bahan seperti yang ada pada laboratorium konvesional, meningkatkan kualitas eksperimen karena memungkinkan untuk diulang untuk memperjelas keraguan dalam pengukuran di lab. Salah satu aplikasi laboratorium virtual adalah simluasi Physics Education Technology (PhET).

The PhET Team (2015) menjelaskan bahwa PhET adalah situs yang menyediakan simulasi pembelajaran fisika, biologi, kimia dan matematika yang diberikan secara gratis oleh Universitas Colorado untuk kepentingan pembelajaran di kelas atau dapat digunakan untuk kepentingan induvidu [2]. Penelitian Antomi mengatakan simulasi dirancang secara interaktif, sehingga penggunaannya dapat melakukan pembelajaran secara langsung [3]. Penelitian ini bertujuan untuk mengetahui peningkatan aktivtas, keterampilan proses sains dan pemahaman konsep melalui model learning cycle $5 E$ berbantuan virtual lab. pada materi usaha dan energi di SMAN 1 Kota Bengkulu. 


\section{METODOLOGI PENELITIAN}

Penelitian ini merupakan penelitian tindakan kelas (PTK), unutk menerapkan metode penelitian kelas dilaksanakan melalui beberapa siklus, dimana tiap siklus terdiri daru perencanaan, tindakan, observasi dan refleksi. Subjek dalam penelitian ini adalah siswa kelas X MIPA2 SMAN 1 Kota Bengkulu dengan variabel yang digunakan yaitu aktivitas, keterampilan proses sains dan pemahaman konsep.

Aktivitas siswa diamati dengan menggunakan lembar aktivitas siswa pada saat proses belajar mengajar berlangsung, sementara itu keterampilan proses sains dan pemahaman konsep dinilai dengan memberikan soal pada akhir pembelajaran. Aktivitas siswa dengan menggunakan tahapan-tahapan model Learning Cycle $5 E$ dengan 10 aspek yang diamati sedangkan keterampilan proses sains denngan menggunakan 5 soal dengan berdasarkan indikator pada keterampilan proses sains, dan 5 soal pemahaman konsep dengan menggunakan indikator yang sesuai. Lembar tes keterampilan proses sains dan pemahaman konsep digunakan untuk mengetahui hasil belajar siswa.

\section{HASIL DAN PEMBAHASAN}

\subsection{HASIL}

Pada penelitian ini, hasil penelitian meliputi lembar aktivitas siswa, hasil belajar keterampilan proses sains serta pemahaman konsep siswa. Pada aktivitas belajar siswa terdapat 10 aspek yang dinilai dengan 5 tahapan yang sesuai dengan model yang digunakan yaitu Learning Cycle 5E. Aktivitas siswa dinilai ketika proses belajar mengajar berlangsung. Setelah dilakukan pengamatan menegenai aktivitas siswa maka hasil observasi aktivitas siswa dapat dilihat pada Tabel 1. berikut.

Tabel 1. Aktivitas Siswa

\begin{tabular}{|c|c|}
\hline Siklus & Nilai Rata-rata \\
\hline I & 25 \\
\hline II & 27 \\
\hline III & 29 \\
\hline
\end{tabular}

Berdasarkan tabel di atas, hasil tes keterampilan proses sains yang digunakan yaitu menggunakan tes keterampilan proses sains yang diberikan pada setiap akhir pembelajaran (akhir siklus belajar), lima indikator yang digunakan yaitu, mengamati, mengajukan pertanyaan, merumuskan hipotesis, menerapkan konsep, dan mengkomunikasikan. Kategori yang digunakan dalam tes hasil belajar ini yaitu dengan rentang Kurang Terampil, Cukup Terampil, Terampil dan Sangat Terampil.

Berdasarkan Permendikbud No.53 Tahun 2015, penilaian keterampilan dianalisis dengan melihat dari hasil tes keterampilan proses sains tersebut [4], dengan penilaian sebagai berikut:

Nilai keterampilan proses sains :

$$
\text { Nilai }=\frac{\text { jumlah skor perolehan }}{\text { jumlah skor maksimal }} \times 100
$$

Tes Hasil Belajar Keterampilan Proses Sains siswa dapat dilihat pada Tabel 2. berikut.

Tabel 2. Tes Hasil Belajar Keterampilan Proses Sains

\begin{tabular}{|c|c|c|c|}
\hline INDIKATOR & SIKLUS & NILAI & KATEGORI \\
\hline \multirow{3}{*}{ Mengamati } & I & $81.60 \%$ & Terampil \\
\cline { 2 - 4 } & II & $90.80 \%$ & Sangat Terampil \\
\cline { 2 - 4 } & III & $95.40 \%$ & Sangat Terampil \\
\hline \multirow{3}{*}{$\begin{array}{c}\text { Mengajukan } \\
\text { Pertanyaan }\end{array}$} & I & $74.60 \%$ & Kurang Terampil \\
\cline { 2 - 4 } & II & $86.20 \%$ & Sangat Terampil \\
\cline { 2 - 4 } Merumuskan & III & $95.40 \%$ & Sangat Terampil \\
\cline { 2 - 4 } Hipotesis & I & $49.10 \%$ & Kurang Terampil \\
\cline { 2 - 4 } & III & $64.65 \%$ & Cukup Terampil \\
\hline Menerapkan & I & $62.20 \%$ & Terampil \\
\cline { 2 - 4 } Konsep & II & $74.48 \%$ & CukupTerampil \\
\cline { 2 - 4 } & III & $95.16 \%$ & Terampil \\
\hline Mengkomunikasikan & I & $82.72 \%$ & Terampil \\
\hline
\end{tabular}




\begin{tabular}{|l|l|l|l|}
\hline & II & $96.52 \%$ & Sangat Terampil \\
\cline { 2 - 4 } & III & $97.24 \%$ & Sangat Terampil \\
\hline
\end{tabular}

Hasil belajar pengetahuan dilihat dengan menggunakan soal tes dalam bentuk essay sebanyak 5 butir soal pemahaman konsep. Adapun perbandingan hasil belajar pengetahuan pemahaman konsep siwa yang diperoleh siswa pada sikus I, siklus II dan siklus III dapat dilihat tabel 3. berikut.

Tabel 3. Hasil Belajar Pemahaman Konsep

\begin{tabular}{|c|c|}
\hline SIKLUS & NILAI RATA-RATA \\
\hline I & 70.17 \\
\hline II & 77.72 \\
\hline III & 89.19 \\
\hline
\end{tabular}

\subsection{PEMBAHASAN}

Penelitian tindakan kelas ini dilakukan untuk mengetahui peningkatan aktivitas, keterampilan proses sains dan pemahaman konsep siswa melalui model learning cycle $5 E$ berbantuan virtual Lab. pada materi usaha dan energi. Berdasarkan hasil penelitian dari siklus I sampai dengan siklus III diketahui bahwa aktivitas siswa sudah dapat dikatakan dalam kriteria baik, dengan terjadinya peningkatan skor di setiap siklus, peningkatan skor di setiap siklus terjadi dikarenakan adanya refleksi. Secara keseluruhan peningkatan aktivitas siswa dapat dilihat dalam Gambar 1. berikut.

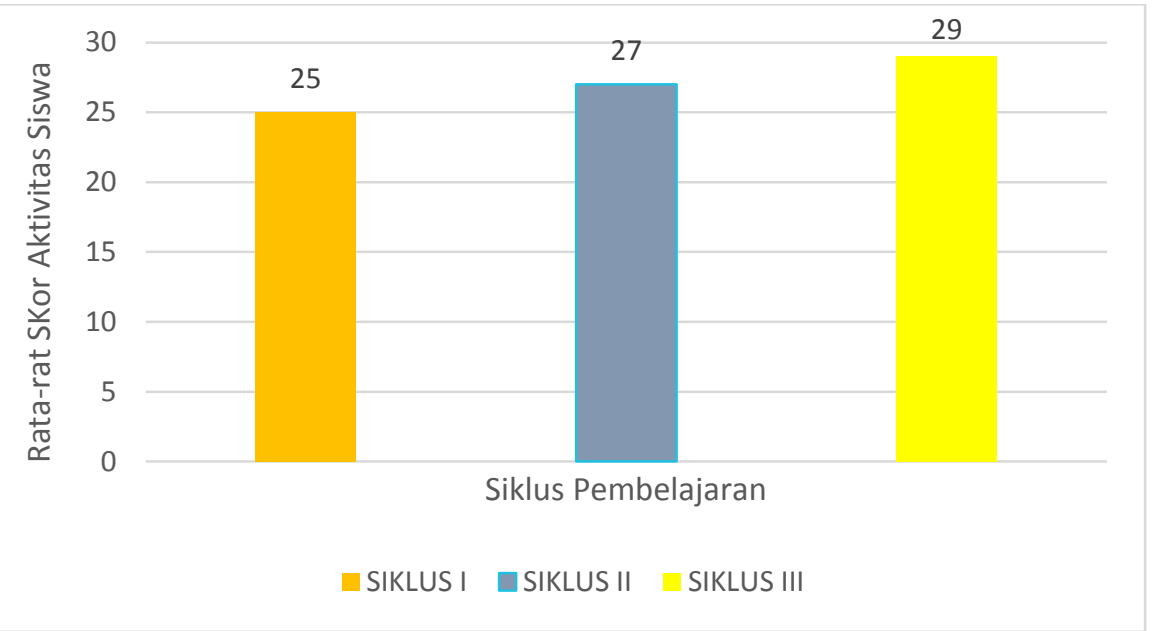

Gambar 1. Grafik Hasil Aktivitas Siswa

Berdasarkan gambar 1 di atas telah diperoleh skor aktivitas siswa yaitu pada siklus I sebesar 25 dengan kategori baik, siklus II skor meningkat menjadi 27 dengan kategori baik dan pada siklus ke III kembali meningkat dengan skor 29. Ada 10 aspek yang dinilai pada aktivitas siswa dengan menggunakan acuan model Learning Cycle 5E. Semua aktivitas siswa telah dilaksanakan dan terdapat beberapa poin pada siklus I yang harus ditingkatkan, sehingga harus dilakukan refleksi yang bertujuan untuk memperbaiki aktivitas siswa pada siklus selanjutnya yaitu siklus II dan pada siklus II telah dilakukan penilaian pada aktivitas siswa, pada siklus ini juga terdapat poin aktivitas siswa yang harus ditingkatkan sehingga dilakukan refleksi untuk meningkatkan aktivitas siswa pada siklus ke III. Setelah dilakukan refleksi di setiap siklusnya, diperoleh skor aktivitas siswa yang meningkat dari siklus I, siklus II hingga siklus III.

Pada siklus III terlihat bahwa aktivitas belajar siswa dengan berbantuan virtual lab. sudah lebih baik dan mengalami peningkatan dari siklus I dan siklus II, disana guru dan siswa telah banyak belajar dari pertemuan pada siklus I dan siklus II, guru lebih mensiasati bagaimana cara agar siswa dapat lebih fokus dalam belajar dan semua siswa dapat mengikuti pelajaran dengan baik dan seksama, guru lebih menekankan dengan media yng digunakan yaitu virtual lab., dengan bantuan virtual lab. siswa lebih mudah memahami praktikum yang dilakukan, karena ini disebabkan dengan ketertarikan dan antusias siswa dalam melihat tampilan media, dimana dengan tampilan tersebut konsep-konsep fisika dapat di 
visualisasikan. Media yang diajarkan ini memudahkan siswa untuk memahami pelajaran yang sedang diajarkan sehingga aktivitas siswa pun berjalan dengan baik. Data yang dihasilkan terjadi peningkatan aktivitas siswa pada tiap siklusnya, dan dengan kriteria baik.

Berdasarkan uraian di atas dapat disimpulkan bahwa aktivitas siswa dengan menggunakan model Learning Cycle 5E untuk memperbaiki aktivitas belajar di kelas X MIPA 2 SMA Negeri 1 Kota Bengkulu telah mengalami perbaikan dan peningkatan. Hal ini didukung oleh penelitian Riza Oktamarina (2016) yang mengungkapkan bahwa "pembelajaran cahaya menggunakan peta konsep melalui siklus belajar 5E dapat meningkatkan aktivitas belajar siswa"[5].

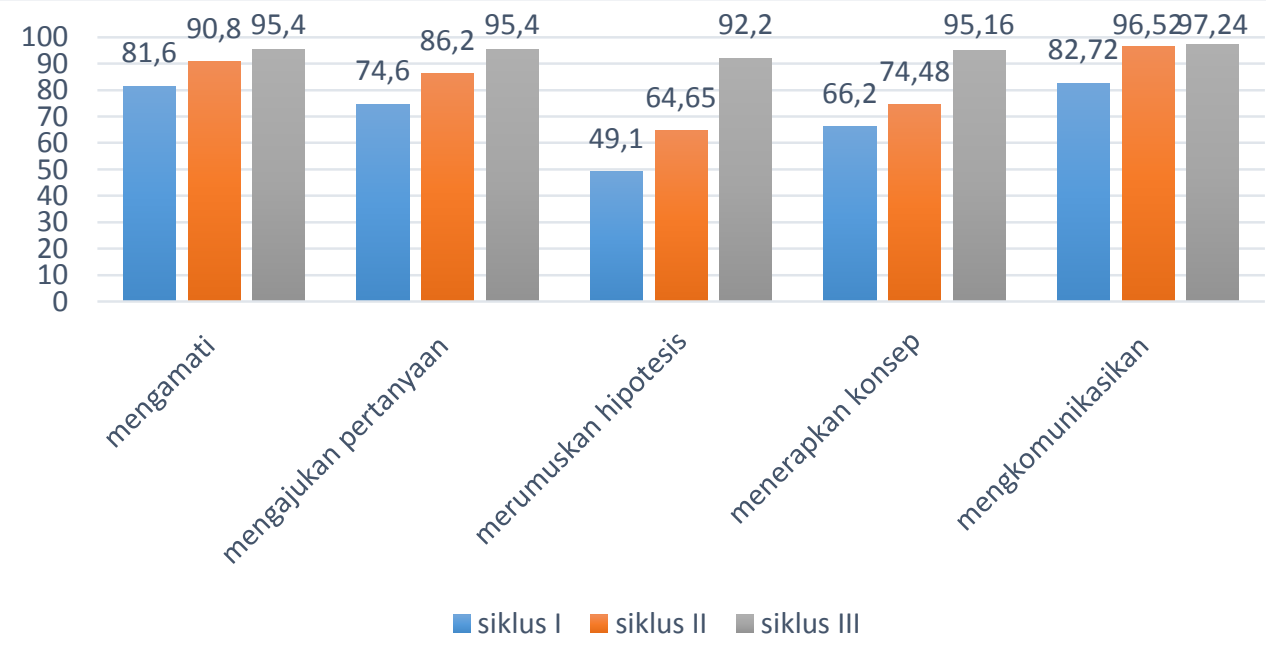

Gambar 2. Grafik Indikator Keterampilan Proses Sains

Pada siklus I pada tabel di atas dapat dilihat bahwa rata-rata yang diperoleh oleh siswa pada indikator mengamati yaitu 81.60 dengan kategori Terampil, siklus II diperoleh rata-rata nilai 90.80 dengan kategori Sangat Terampil dan pada siklus III meningkat lagi menjadi 95.40 dengan kategori Sangat Terampil, pada indikator membuat pertanyaan pada siklus I diperoleh rata-rata nilai yaitu 74.60 dengan kategori Terampil, nilai rata-rata 86.20 dengan kategori Sangat Terampil pada siklus II dan meningkat lagi menjadi 95.40 dengan kategori Sangat Terampil pada siklus III, pada indikator merumuskan hipotesis nilai rata-rata yang diperoleh siswa yaitu pada siklus I 49.10 dengan kategori Kurang Terampil, nilai rata-rata 64.65 dengan kategori Cukup Terampil pada siklus II dan meningkat menjadi 92.20 dengan kategori Sangat Terampil pada siklus III, pada indikator menerapkan konsep nilai rata-rata yang diperoleh yaitu 66.20 dengan kategori Kurang Terampil, meningkat menjadi 74.48 dengan kategori Terampil, pada siklus II dan meningkat lagi menjadi 95.16 dengan kategori Sangat Terampil pada siklus III dan terakhir pada indikator mengkomunikasikan dengan nilai rata-rata yang diperoleh pada siklus I yaitu 82.72 dengan kategori Terampil, meningkat menjadi 96.51 dengan kategori Sangat Terampil dan meningkat lagi menjadi 97.24 dengan kategori Sangat Terampil. Nilai rata-rata siklus I sampai dengan siklus III ini menunjukkan bahwa terjadinya peningkatan yang signifikan terhadap keterampilan proses sains, peningkatan ini terjadi dikarenakan beberapa faktor salah satunya dengan bantuan media yang digunakan yaitu media virtual lab. dengan aplikasi PhET, dimana pada proses pembelajaran berlangsung, siswa melakukan praktikum menggunakan Lembar Kerja Peserta didik yang langkah-langkahnya disesusaikan dengan aspek keterampilan proses sains, sehingga membuat siswa menjadi lebih antusias hal ini menunjukan bahwa hasil belajar siswa kelas $\mathrm{X}$ MIPA 2 SMA N 1 Kota Bengkulu sudah meningkat dan dapat dikatakan telah sesuai dengan Kriteria Ketuntasan Minimum (KKM) di SMA N 1 Kota Bengkulu.

Nilai rata-rata siklus I sampai dengan siklus III ini menunjukkan bahwa terjadinya peningkatan yang signifikan terhadap keterampilan proses sains, peningkatan ini terjadi dikarenakan beberapa faktor salah satunya dengan bantuan media yang digunakan yaitu media virtual lab. dengan aplikasi PhET, dimana pada proses pembelajaran berlangsung, siswa melakukan praktikum menggunakan Lembar 
Kerja Peserta didik yang langkah-langkahnya disesusaikan dengan aspek keterampilan proses sains, sehingga membuat siswa menjadi lebih antusias hal ini menunjukan bahwa hasil belajar siswa kelas $\mathrm{X}$ MIPA 2 SMA N 1 Kota Bengkulu sudah meningkat dan dapat dikatakan telah sesuai dengan Kriteria Ketuntasan Minimum (KKM) di SMA N 1 Kota Bengkulu.

Peningkatan hasil belajar keterampilan proses sains pada tiap siklus ini menjelaskan bagaimana penguasaan siswa terhadap materi yang diajarkan, dalam hal ini peran guru sebagai motivator. Dari uraian di atas dapat kita simpulkan bahwa penerapan model Learning Cycle $5 E$ dapat meningkatkan keterampilan proses sains siswa. Hal ini didukung oleh penelitian (Retnaningati, Maridi, \& Sugiharto, 2011) yang mengungkapkan bahwa adanya "Penerapan Model Pembelajaran Siklus Belajar (Learning Cycle) untuk Meningkatkan Keterampilan Proses Sains Siswa Kelas X-2 SMA Negeri 3 Surakarta Tahun Pelajaran 2010/2011" [6].

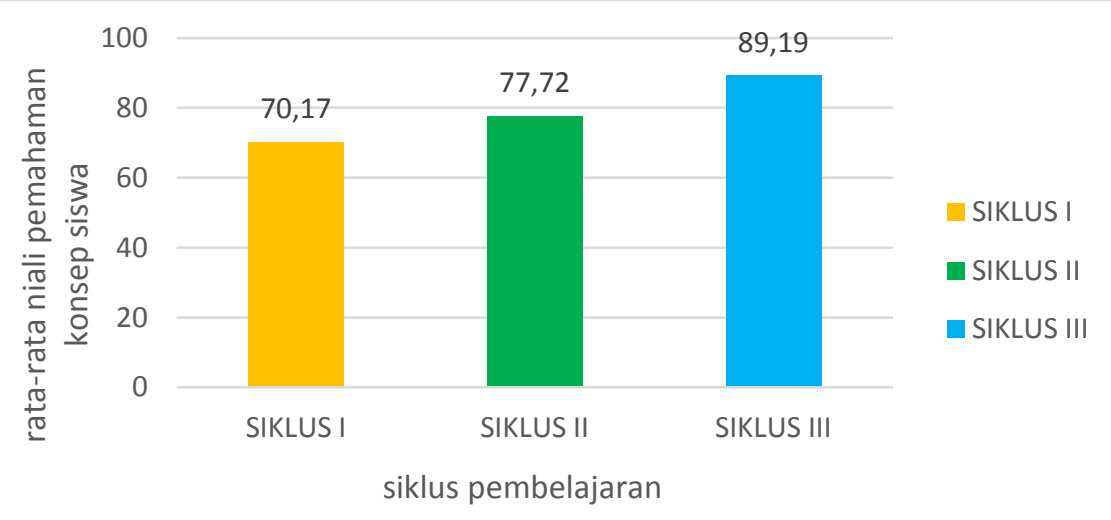

Gambar 3. Nilai Rata-rata Pemahaman Konsep

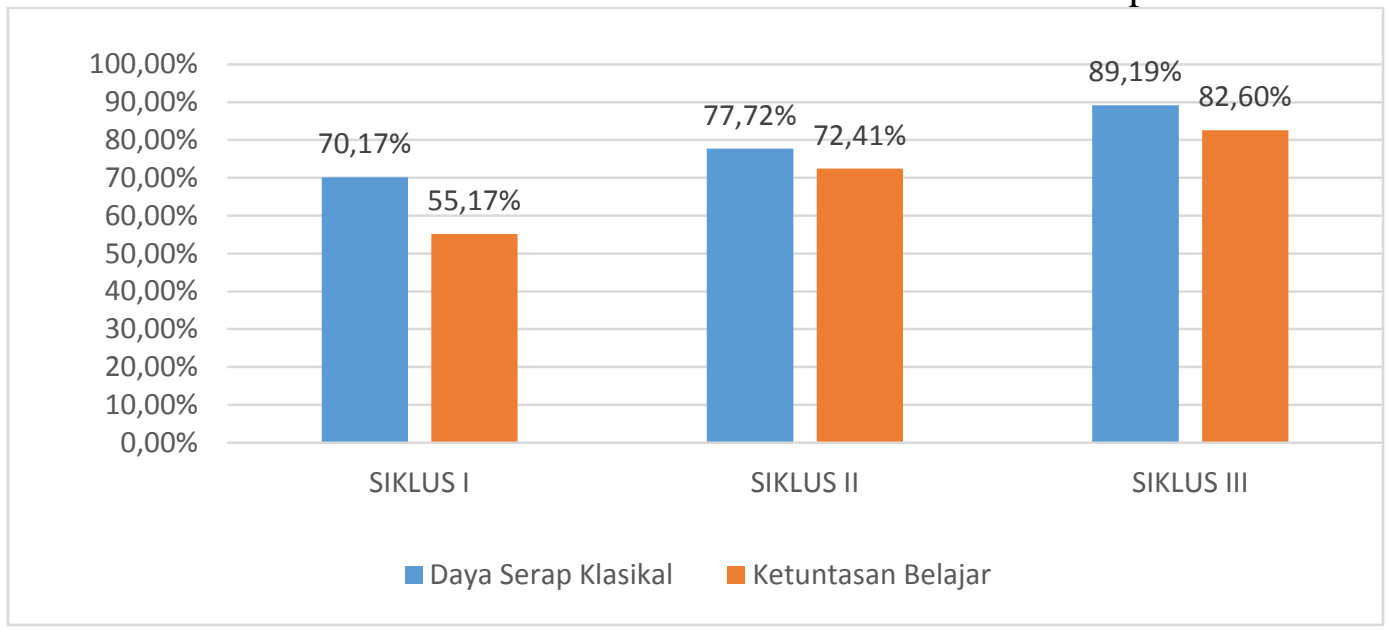

Gambar 4. Daya Serap, dan Ketuntasan Belajar

Pada Gambar 3 dan Gambar 4 di atas dapat dilihat bahwa persentase ketuntasan belajar siswa mengalami peningkatan. Untuk siklus I diperoleh skor rata-rata siswa 70.17 dengan daya serap $70.17 \%$ dan ketuntasan belajar siswa 55.17\%. Siklus II skor rata-rata siswa meningkat menjadi 77.72 dengan daya serap $77.72 \%$ dan ketuntasan belajar siswa menjadi $72.41 \%$. Hal ini menunjukan bahwa hasil belajar siswa kelas X MIPA 2 SMA N 1 Kota Bengkulu sudah meningkat. Ini diperkuat lagi dengan hasil belajar pada siklus III yang diperoleh skor rata-rata sebesar 89.19 dengan daya serap 89.19\%, dan ketuntasan belajar yang mencapai 86.20\%. Menurut Sani dalam penelitiannya mengatakan guru mengevaluasi pemahaman peserta didik tentang pemahaman konsep dan penguasaan keterampilan. Peserta didik menerima umpan balik tentang kesesuaian eksplorasinya dan guru dapat menggunakan prosedur formal atau informal untuk evaluasi. Pada tahap ini dapat dilakukan dengan melakukan penilian baik tes, observasi, jurnal, portofolio [7]. 


\section{KESIMPULAN}

Berdasarkan penelitian ini diperoleh beberapa kesimpulan bahwa strategi pemecahan masalah dalam pembelajaran yang ditinjau dari gaya belajar siswa kelas X adalah : (a) Penerapan model pembelajaran Learning Cycle $5 E$ berbantuan virtual lab. dapat meningkatkan aktivitas belajar siswa pada materi Usaha dan Energi. Skor rata-rata aktivitas belajar siswa sebesar 25 dengan kategori baik pada siklus I meningkat menjadi 27 dengan kategori baik pada siklus II, dan kembali meningkat menjadi 29 dengan kategori baik pada siklus III. Artinya indikator kinerja aktivitas siswa telah tercapai. (b) Penerapan model pembelajaran Learning Cycle 5E berbantuan virtual lab. dapat meningkatkan keterampilan proses sains siswa kelas X MIPA2 SMA Negeri 1 Kota Bengkulu pada materi Usaha dan Energi. Keterampilan proses sains siklus I pada aspek mengamati diperoleh nilai rata-rata 81.6 (Terampil), siklus II 90.8 (Sangat Terampil), siklus III 95.4 (Sangat Terampil), selanjutnya pada aspek mengajukan pertanyaan pada siklus I diperoleh nilai rata-rata 74.67 (Terampil), siklus II 86.2 (Sangat Terampil), siklus III kembali meningkat menjadi 95.4 (Sangat Terampil), pada aspek merumuskan hipotesis siklus I dengan nilai rata-rata 49.1 (Kurang Terampil), siklus II 64.65 (Cukup Terampil) dan siklus III 95.4 (Sangat Terampil), selanjutnya aspek menerapkan konsep pada siklus I dengan nilai rata-rata 66.2 (Cukup Terampil), siklus II 96.52 (Sangat Terampil) dan siklus III meningkat menjadi 97.24 (Sangat Terampil) dan terakhir pada aspek mengkomunikasikan pada siklus I dengan nilai rata-rata 82.72 (Terampil), pada siklus II 96.52 (Sangat Terampil) dan pada siklus III meningkat kembali menjadi 97.24 (Sangat Terampil). (c) Penerapan model pembelajaran Learning Cycle $5 E$ berbantuan virtual lab. dapat meningkatkan pemahaman konsep siswa kelas X MIPA2 SMA Negeri 1 Kota Bengkulu pada materi Usaha dan Energi. Hasil belajar pada aspek pemahaman konsep diperoleh skor rata-rata 70.17 pada siklus I meningkat menjadi 77.72 pada siklus II dan 89.19 pada siklus III. Daya serap sebesar $70.17 \%$ pada siklus I meningkat menjadi $77.72 \%$ pada siklus II dan $89.19 \%$ pada siklus III dengan ketuntasan belajar sebesar pada siklus I yaitu 55.17\%, meningkat menjadi pada siklus II menjadi $72.41 \%$ dan meningkat lagi menjadi $86.20 \%$ pada siklus III.

\section{DAFTAR PUSTAKA}

[1] Antomi, S. (2016). Pembelajaran Pengantar Fisika Kuantum dengan Memanfaatkan Media PhET Simulation dan LKM melalui Pendekatan Saintifik : Dampak pada Minat dan Penguasaan Konsep Mahasiswa . jurnal Pendidikan.

[2] Dedy, H., Eva, K., \& Indra, S. (2012). Pengaruh Model Pembelajaran Generatif dengan Menggunakan Alat Peraga terhadap Pemahaman Konsep Cahaya Kelas VIII di SMP Negeri 7 Kota Bengkulu. Jurnal Exacta.

[3] Dina, L. S., Rosane, M., \& Nyoman, R. (2017). Penerapan Model Discovery Learning Untuk Meningkatkan Hasil Belajar Kognitif dan Keterampilan Proses Sains di Kelas VII.B SMP Negeri 10 Kota Bengkulu. jurnal pendidikan .

[4] Kurniawan, A. D. (2013). Metode Inkuiri Terbimbing Dalam Pembuatan Media Pembelajaran Biologi Untuk Mengingkatkan Pemahaman Konsep dan Kreativitas Siswa SMP.

[5] Oktamarina, R. (2016). Pembelajaran Cahaya Menggunakan Peta Konsep Melalui Siklus Belajar Tipe 5E Untuk Meningkatkan Hasil Belajar dan Aktivitas Belajar Siswa Di Kelas VIII 1 SMP 1 Kota Bengkulu.

[6] Retnaningati, D., Maridi, \& Sugiharto, B. (2011). Penerapan Model Pembelajaran Siklus Belajar (Learning Cycle) untuk Meningkatkan Keterampilan Proses Sains Siswa Kelas X-2 SMA Negeri 3 Surakarta Tahun Pelajaran 2010/2011 . Pendidikan Biologi FKIP .

[7] Sani, R. A. (2013). Inovasi Pembelajaran. PT Bumi Aksara. 